\title{
Kelompok Sempalan: Sisi Lain Dinamika Politik Kita
}

\author{
Muhammad Idrus
}

The arising of illegal political groups relatively represent the Indonesian leadership patterns. In ORBA, these groups emerge as the manifestation of the twarthened politic communication and of the oppresive policy in finding the conflict solutions. There are many various kinds of illegal political groups that generally can be assimilated as reaction toward the unsolved crisis and of imbalance development policies that destroy the human values. As a response to the illegal politic groups whose emergences are identified as violence movements, the government should make any systematical improvements. One of them-according to the writer of this book-should be conducted by maintaining the democracy in Indonesia.

\section{Pengantar}

ebagai makhluk sosial, manusia dengan sendirinya tidak dapat melepaskan diri dari lingkungan sosial sekitarnya. Dia harus melakukan komunikasi dengan sesamanya. Dalam jalinan komunikasi tersebutlah muncul saling memahami antara seseorang dengan orang lainnya. Di sinilah timbul rasa solidaritas antar sesama. Pada giliran selanjutnya rasa solidaritas tersebut memunculkan empati di antara sesama, sehingga seseorang dapat merasakan kesedihan dan kesenangan yang dirasakan sahabatnya.

Dalam bukunya yang berjudul The Division of Labour in Society, Sosiolog Perancis, Emile Durkheim, mengemukakan secara panjang lebar tertang solidaritas ini. Durkheim, membagi ikatan solidaritas di antara sesama manusia menjadi dua, yaitu solidaritas mekanik dan solidaritas organik. Solidaritas mekanik berkembang secara pesat di kalangan masyarakat tradisional, yang lebih mengutamakan hubungan emosional dan sentimentil, serta dalam format hubungan yang tidak jelas. Pada posisi tersebut kekerabatan, persamaan ras suku, agama (kepercayaan) di atas segalanya.

Sementara itu, solidaritas organik berkembang di masyarakat moderen, dengan meninggikan kebertungsian diri atas lingkungan sekitarnya. Pada masyarakat semacam ini telah ada pembagian kerja yang jelas. Melihat perkembangan sejarah, tampak di hadapan kita ikatan solidaritas yang hadir dalam panggung sejarah Indonesia mengalami fluktuasi. Terlebih jika hal tersebut dikaitkan dengan latar belakang sosial mereka yang melakukannya. 
Topik: Kelompok Sempalan: Sisi Lain Dinamika Politik Kita, Muhammad Idrus

Puncak kejayaan ikatan solidaritas tersebut di Indonesia dicapai dengan dijadikannya negara ini sebagai rujukan bagi contoh pola hubungan antar agama yang harmonis hingga menjelang akhir jaman orde baru. Pada masa itu, tidak ada seorang sosiolog pun yang berani meramalkan akan porak porandanya ikatan manis persaudaraan baik antar agama, ataupun antar suku di Indonesia.

Tampakya bingkai manis solidaritas yang terjalin tersebut saat ini tercabik dengan munculnya pelbagai kerusuhan yang melibatkan bukan hanya suku, tetapi juga simbol-simbol agama. Bahkan muncul pandangan yang menyatakan seakan-akan agama adalah pemicu terjadinya konflik tersebut. Benarkah seluruh konflik tersebut berawal dari agama?² Jika belakangan ini terjadi aksi-aksi yang menjurus pada tuntutan berdirinya negara dalam negara, benarkah institusi agama juga ikut terlibat di dalamnya atau ada kekuatan lain yang mengarahkan massa untuk melakukan perilaku tersebut.

\section{Kehadiran Agama dan Konflik yang Ditimbulkannya}

Sebelum menerima pelbagai ajaran agama wahyu, masyarakat awal Indonesia telah memiliki kepercayaan yang diyakini sejak nenek moyang mereka. Sebut saja beberapa kepercayaan awal mereka, seperti Kahirangan di pedalaman Kalimantan, suku Baduy yang juga memiliki kepercayaan yang "khas" hingga saat ini, serta beberapa suku lain yang jumlahnya sangat banyak. Hadirnya agama Hindu dan Budha lebih awal dibanding agama Islam dan Kristen. Kedua agama tersebut pada akhirnya mewarnai seluruh kawasan Nusantara yang masih berbentuk kerajaan, serta menjadi agama resmi bagi kerajaan yang ada.
Pada abad 7, masuklah agama islam ke Nusantara. Islam yang dibawa oleh para saudagar (Persia) tersebut nampaknya dapat diterima secara baik oleh hampir kebanyakan masyarakat nusantara. Meski ada beberapa yang menolak kehadirannya, tetapi tampaknya masuknya Islam ke nusantara dapat dikatakan ralatif tanpa membawa pertumpahan darah yang berarti seperti di negara asalnya.

Berbeda dengan perkembangan Islam di "tanah kelahirannya". Islam yang masuke dan bèrkembang di bumi nusantara ini. lebih berbaju kedamaian dan perkembangan-

'Sejarah membuktikan — saat itu - betapa masyarakat Mustim dan Kristen di Ambon dapat rukun dalam ikatan Pela-Gandong. mereka saling bahu membahu dalam aktivitas bermasyarakatnya. Bahkan dalam pembangunan rumah ibadah mereka melakukannya secara gotong royong. Namun sejak Ramadhan $1419 \mathrm{H}$ yang lalu, persaudaraan itu luluh lantak tergusur fenomena kekerasan. Hingga hari ini "pertikaian saudara" di Ambon belum dapat terselesaikan dengan baik. Peristiwa Sambas, atau yang baru-baru ini di Halmahera juga mengindikasikan betapa mulai terkoyaknya ikatan solidaritas antar etnis.

2Padahal di lain sisi, agama merupakan pelindung bagi para umatnya dalam menghadapi situasi krisis dan penyejuk jiwa manakala seluruh intitusi sosial yang ada tak mampu melakukannya.

${ }^{3}$ Ada tiga (3) teori yang menjelaskan tentang kapan dan siapa yang membawa misi Islam pertama di Nusantara. Teori pertama dikenal dengan teori Gujarat, yang menjelaskan bahwa yang membawa Islam pertama kali adalah para pedagang dari daerah Gujarat pada abad 13, teori kedua adalah teori Persia, bahwa yang membawa Islam adalah para pedagang dari Persia pada abad 13. Teori ketiga adalah teori Makah yang dikemukakan oleh Prof. Dr. Hamka, yang menjelaskan bahwa yang membawa Islam adalah para pedagang dari Arab pada abad 7. 
nya juga cenderung menjauh dari kekerasan, termasuk dalam masalah-masalah kekuasaan. Rasionalitas yang menguatkan fenomena ini karena perkembangan Islam di sini "berkawin" dengan faktor kultural bangsa yang mendiami kawasan ini, khususnya bangsa Melayu yang mendominasi kawasan Indonesia saat itu.

S'ekalipun Islam yang masuk ke indonesia adalah Islam yang telah "berkabung dengan dosa sejarah" -meminjam istilah yang digunakan Ahmad Syafii Maarifnamun tampaknya perkembangannya di kawasan nusantara tidak melanjutkan "episode pertumpahan darah" seperti di awal masa perkembangannya di negeri asalnya. Bahkan Maulana Malik Ibrahim yang berperan dalam menyebarkan Islam di Jawa, sebagai pusat pemerintahan modern nusantara masa itu misalnya, justru berhasil memanfaatkan kekuasaan para raja dan kaum bangsawan di wilayah ini untuk lebih mengembangkan dakwah Islamiyah, sehingga pada akhirnya raja dan banyak kaum bangsawan Jawa yang menganut agama Islam, meski untuk hal itu mereka tetap tidak menyatakannya sebagai agama resmi negara.

Tampaknya Islam yang berkembang di nusantara ini telah mengalami proses sterilisasi, secara kultural dari apa yang disebut dengan idiom "Islam disebarkan dengan pedang" dalam masa perkembangan sebelumnya di wilayah budaya masyarakat lain. Artinya perkembangan Islam baik di tanah Jawa, demikian juga di berbagai daerah lainnya di nusantara (terutama kawasan pantai seperti Pașai), tidak memer lukan kekerasan (pedang), dan kehadirannya tidak pula memicu lahirnya kelas kekuasaan baru, sekalipun para raja dan keluarganya pada masa itu juga menyatakan dirinya masuk Islam.

Bahkan justru sebaliknya, bagi rakyat kebanyakan kehadiran Islam disamakan dengan masa Renaisans, yang memberi pencerahan bahwa hidup harus dinikmati dengan sebaik-baiknya layaknya akan hidup selamanya yang selalu dalam kerangka ibadah, yang disertai keșadaran ibadah seperti ajal yang akan menjemput esok hari. Selain itu, hadirnya Islam melahirkan kelompok baru yang disebut ulama dan santri yang pada kehidupan selanjutnya di episode sejarah bangsa ini memberi kontribusi yang signitikan bagi masyarakat bangsa ini dalam upaya pembebasan atas penjajahan bangsa asing.

Pengaruh para ulama Islam terhadap raja-raja Jawa tampak begitu kentara tatkala secara cermat mengamati sejarah lampu Islam di tanah Jawa. Dari sejarah kerajaan Islam di Jawa, ditengarai betapa besar pengaruh yang dimiliki Sunan Kudus, sebagaimana yang diceritakan Graff (1985) bahwa dalam masa pergolakan politik kerajaan Demak pasca Sultan Trenggana, tatkala terjadi pertikaian antara Jaka Tingkir (kelak bergelar Sultan Hadiwijaya) di Pajang dan Ario Penangsang sang penguasa Jipang. Fachry Ali menuturkan situasi itu, dengan. menghadirkan Sunan Kudus sebagai pendamai dalam pertikaian politik tersebut, Sunan Kudus "memanggil" kedua elite kerajaan tersebut untuk datang kepadanya. Setelah "mendamaikan" dengan memarah" keduanya, lalu keduanya disuruh pulang dengan membawa nasihatnya untuk tidak melanjutkan perselisihan ini.

Realita tersebut memang bukañ sematamata karena faktor budaya, tetapi juga kàrena pendekatan dalam kedatangan Islam yang persuasif-kultural sebagaimana yang

${ }^{4} \mathrm{Hal}$ ini secara tidak langsung menunjukkan betapa berpengaruhnya kaum ulama terhadap para bangsawan. Meski demikian, sejarah mencatat perselisihan tersebut harus berakhir dengan perang tanding keduanya. 
dicontohkan Nabi, bersambut dengan "kebingungan" masyarakat bangsa mengenaikepercayaan yang dapat menenangkanlahir dan batin. Inilah kehidupan yang kita lihat dalam perkembangan Islam yang disebarJuaskan para wali, dengan cara yang senantiasa berpijak pada pendekatan yang menghormati unsur kemanusiaan dan sosial budaya masyarakat setempat.

Sejak awal hadirnya kaum kolonial, mulailah terjadi pergeseran paradigma keberagamaan (khususnya Islam). Agama yang semula banyak dimaksudkan sebagai sarana untuk menemukan ketenangan batiniah, maka hadirnya penjajah Belanda yang kebetulan beragama Nasrani- di bumi nusantara memicunya sebagai alat pemersatu untuk secara bersama menghadapi bangsa penjajah. Selain itu hadirnya penjajah di bumi Indonesia memicu munculnya pelbagai gerakan kebangsaan yang bermuara pada keinginan mewujudkan eksistensi berbangsa yang berdaulat. Dalam situasi ini para pemimpin Islam hadir dalam kancah perjuangan fisik, dan muncul dalam wujud gerakan-gerakan yang berorientasi sosial kemasyarakatan, khususnya dalam upaya membela tanah airnya dengan mengobarkan semangat jihad. ${ }^{5}$

Sejak itu Islam sebagai salah satu ikatan dalam mempertahankan kedaulatan bangsa, dan memposisikan hampir sama dengan perkembangannya di jazirah Arab dengan melibatkannya dalam situasi politik. Tampaknya menyeret Isłam dàlam kancah politik ini membawa hasil yang menakjubkan, dengan bukti sulitnya Belanda menaklukkan daerah-daerah yang berjuang di bawah komando pemimpin agama seperti Pangeran Diponegoro, Tuanku Imam Bonjol, Teuku Umar, Tjut Nyak Dien, - sekedar menyebut beberapa-. Dari sisi ini tampaknya begitu efektif untuk menggerakkan masyarakat bangsa ini atas nama agama. Pada giliran berikutnya fenomena ini terka- dang menimbulkan kerinduan pada sejarah kejayaan "negara Islam" sebagaimana pernah dialami masa-masa pemerintahan islam di negara asalnya sehingga muncul keinginan untuk mewujudkannya dalam kehidupan bernegara. Harus diakui, fenomena tersebut menjadi obsesi beberapa pemimpin perge rakan Islam pra kemedekaan.

Hingga akhir abad 19, diskursus tentang Islam sebagai suatu state tampaknya tetap marak di kalangan pemimpin Islam, dan terus menjadi cikal bakal hadirnya kelompokkelompok dissident - yang dikemudian hari melahirkan Islam sempalan dalam ideologi?

Berbeda dengan hadirnya Islam di nusantara, kedatangan agama Kristen yang dibawa para misionaris dan zending -yang hadir bersamaan dengan hadirnya masya rakat barat (Bangsa Belanda) - identik dengan kehadiran para penjajah di Nusantara. Mengingat watak penjajahnya, maka banyak kalangan pembesar kerajaan nusantara yang menolak kehadiran mereka pada awalnya konflik terjadi karena masyarakat nusantara tidak menerima perlakuan penjjah. Secara kebetulan, mayoritas penggerak perlawanan terhadap penjajah adalah para bangsawan, pangeran, ataupun sultan yang beragama Islam. Pada giliran berikutnya secara tidak sadar kondisi tersebut menjadi embrio bagi konflik antar agama. Dalam hal ini, sebut saja Islam di satu sisi dan Kristen di sisi lain.

Terlebih doktrin yang dikumandangkan para pemimpin (agama) Islam dengan mengobarkan semangat para pengikutnya

5Dalam analisisnya Harry J. Benda me nyatakan bahwa partisipasi perjuangan ulama dan kelompok santri telah berlangsung sejak awal kedatangan Portugis pada tahun 1511 (Kontiunitas dan Perubahan dalam Islam di Indonesia, Taufik Abdullah (Editor), 1974. Jakarta: Tintamas). 
untuk melawan penjajah, dan menyatakan bahwa memerangi mereka (para penjajah) merupakan jihad $f i$ sabilillah. Dengan demikian, konflik yang mudah dimaksudkan untuk menentang hadirnya penjajah, maka pada tahap berikutnya bergeser menjadi konflik antar agama. Untungnya, pada giliran berikutnya konflik tersebut dapat diproporsionalkan, dan tetap sebagai konflik antar penjajah dengan mereka yang terjajah. Meski banyak yang belum menyepakati bahwa konflik antara penjajah (Belanda, dan Inggris - untuk beberapa saat) dengan si terjajah merupakan pemicu konflik eksternal agama. Namun, tampaknya hal tersebut perlu menjadi catatan mulai hadirnya konflik agama.

Terlebih pada lanjutan sejarah berikutnya, pada banyak situasi kelompok terakhir ini tampak begitu mesra dengan penguasa negara. Sementara di sisi lain, Islam kerap menjadi kelompok yang ditengarai mengalami proses marginalisasi, dan harus pula diakui bahwa umat Islam kerap menerima sebagai kelompok pecundang (the losser).

Membaca șejarah di atas, maka secara potensial agama memang dapat dijadikan sebagai satu kekuatan untuk "menyempal" baik secara ideologi, maupun state, meski demikian harus pula diakui ada potensi lain yang memiliki peluang sama untuk menjadi kelompok sempalan. Dalam konteks ini setidaknya perilaku menyempal dalam kehidupan negara kita dapat diidentifikasi menjadi 3 kelompok besar, yaitu (1) yang berdasar agama; (2) yang berdasar pada keyakinan ideologi dan (3) etnis.

\section{Mempertimbangkan Potensi Islam}

Satu hal yang menarik dalam perjalanan sejarah bangsa ini, yaitu jika ada agama yang secara terang-terangan sebagai basis gerakan sempalan, ${ }^{6}$ maka hal itu me- rujuk pada agama Islam. Memang harus diakui bahwa keinginan memunculkan Islam bukan sekadar sebagai agama ritual, mulai tampak tatkala jatuhnya kekuasaan Belanda ke tangan serdadu Jepang.

Tampaknya para pemimpin pergerakan Islam itu menginginkan Islam sebagai ideologi bagi negara yang akan dibentuk kelak. Meski demikian, pada rapat-rapat BPUPKI (Badan Penyelidik Usaha Persiapan Kemerdekaan Indonesia) para pemimpin pergerakan Islam tidak siap untukmelontarkan gagasan mereka tentang Islam sebagai suatu state. Pada akhirnya seluruh anggota sidang sepakat untuk menerima konsep yang diajukan Ir. Soekarno tentang dasar negara -yang kemudian disebut dengan Pancasila - yang sebenarnya merupakan sintesa dan berbagai jeologi Barat terutama nasionalisme, Demokrasi, Sosialisme, Internasionalisme, dan ketuhanan yang merupa kan kontribusi ide dari kelompok keagamaan.

Untuk yang terakhir ini kelompok agama (Islam) menginginkan format sila tersebut ditambahi kalimat "dengan menjalankan syari'at Islam bagi pemeluk-pemeluknya" sebagaimana tercatat dalam piagam Jakarta. Namun, tampaknya keinginan tersebut harus kembali diredam tatkala berhadapan dengan kepentingan nasional yang lebih luas, maka dengan dalih persatuan kalimat tambahan -yang di kemudian hari dikenal dengan tujuh kata- ditiadakan. Untuk itu sebagai kompensasinya kelompok ini meminta beberapa tambahan tentang sila ketuhanan, yaitu menambahkan predikat "Yang Maha Esa" di belakang kata

${ }^{6}$ Gerakan sempalan yang dimaksud dalam tulisan ini adalah gerakan perlawanan terhadap negara yang syah dan bermaksud untuk mendirikan satu bentuk bernegara baik berdasarkan ikatan agama, ideologi, ataupun ikatan emosional lainnya (misalnya etnis). 
ketuhanan, menempatkan sila ini sebagai sila pertama dari rangkaian sila-sila yang ada, dan terakhir menjadikannya sebagai nilai yang paling dasar, serta mendasari nilai-nilai yang ada (Rahardjo, 1992). Bagi Maarif (1995), masa-masa itu dan masamasa selanjutnya hingga tahun 1959 disebutnya sebagai masa "pertarungan seru" antara Islam dan Pancasila.?

Dalam catatan sejarah, tampaknya ide untuk menjadikan Islam sebagai ideologi negara tampak menguat kembali setelah berlangsungnya Pemilihan Umum 1955, ketika itu Dewan Konstituante yang dibentuk diberi kesempatan untuk menyusun UUD baru. Meski Moh. Natsir, dkk. telah memberi gambaran lengkap tentang wawasan keislaman dalam bernegara yang relatif lebih siap dibanding saat pemimpin gerakan Islam menjelang kemerdekaan-, namun sidang belum dapat menerima keinginan kelompok ni untuk menjadikan Islam sebagai ideologi negara, kegagalan tersebut tentu. saja salah satunya disebabkan kecilnya perolehan suara fraksi-fraksi Islam, di samping masih adanya ketidaksamaan antar fraksi itu sendiri tentang landasan filosofis kepartaian, ataupun harapan individual anggota fraksi Islam.

Banyaknya kegagalan dalam upaya diplomasi dirasakan para pemimpin Islam garis keras untuk menempuh cara lain. Salah satunya dilakukan oleh Sangaji Marijan Kartosuwiryo yang melakukan aksi dengan mencetuskan berdirinya Negara Islam Indonesia (NII). Dukungan hadirnya NII muncul dari beberapa kantong-kantong islam, seperti Aceh (Daud Beureuh), Sulawesi Selatan (Kahar Muzakkar), dan beberapa kantong Islam di Jawa.

Meski pada akhirnya gerakan ini dapat ditumpas oleh aparat keamanan, namun tampaknya tidak dapat menyurutkan para pemimpin garis keras ini untuk terus "ber- juang" menegakkan cita-citanya. Perjalanan waktu ternyata tidak menyurutkan cita-cita tersebut, dan situasi ini pada akhirnya mendorong penguasa untuk bersikap lain pada umat Islam. Bahkan dalam catatan Tempo (1999) disebutkan bahwa era sebelum tahun 1990-an ditandai dengan kebijakan anti Islam yang mencolok, antaa lain lewat penciptaan fiksi "fundamentalisme dan terorisme Islam".

Sikap penguasa itu begitu kentara, sehingga banyak kasus pemboman yang dilakukan kelompok-kelompok orang tertentu lalu dengan begitu saja diidentikandengan kelompok Islam. Sebut saja temuan beberapa kasus pemboman yang terjadiantara tahun 1976-1999, yang ujung-ujungnya merujuk pada kelompok Islam (beberapa kasus pemboman dapat dilihat pada tabel 1).

Selain itu dalam upayanya menjauhkan masyarakat dari kegiatan politik (depolitisasi masyarakat), maka pemerintah mulai membatasi ruang gerak orsospol dan ormas

'Puncak pertarungan itu tampaknya menjadikan Islam sebagai kelompok yang mengalami kekalahan, yaitu dengan hadirnya UU tentang keormasan tahun 1982, yang mewajibkan seluruh organisasi kemasyarakatan memakai azas Pancasila, sebagai azas satusatunya organisasi. Banyak organisasi yang harus "berganti baju" dengan menjadikan Pancasila sebagai ideologi organisasinya. Meski demikian, kondisi tersebut berubah tatkala muncul gerakan reformasi dengan hasil longsornya Soohurto dari kursi koprosidenan. Sejak saat itu, mulailah terjadi pembelikan ideologi organisasi, dan lenomena ini marak tatkala menjelang Pemilu lahun 1999 dengan munculnya partai-partai politik yang secara resmi berasaskan Islam. Bahkan yang lebih mengejutkan adalah hadirnya Partai Rakyat Demokratik (PRD) yang pada masa Orde Baru diklaim sebagai organisasi partai politik yang kental dengan nuansa komunis. 
Topik: Kelompok Sempalan: Sisi Lain Dinamika Politik Kita, Muhammad Idrus

Tabel 1 Kasus Pemboman yang diidentifikasi dilakukan kelompok Islam

\begin{tabular}{|c|c|c|c|c|}
\hline Kasus & Tanggal & Tersangka & Identitas & Keterangan \\
\hline $\begin{array}{l}\text { Masjid Nurul Iman, } \\
\text { Padang }\end{array}$ & $11-11-1976$ & $\begin{array}{l}\text { Timzar } \\
\text { Zubil }\end{array}$ & $\begin{array}{l}\text { Tokoh Komando } \\
\text { Jihad }\end{array}$ & $\begin{array}{l}\text { Ybs, tidak } \\
\text { ditemukan }\end{array}$ \\
\hline BCA Pecenongan & $4-10-1984$ & M. Jayadi & $\begin{array}{l}\text { Anggota Gerakan } \\
\text { Pemuda Ka'bah }\end{array}$ & $\begin{array}{l}\text { Ybs, tidak } \\
\text { dikenal anggota } \\
\text { GPK }\end{array}$ \\
\hline BCA Gadjah Mada & $4-10-1984$ & Edi Ramli & Anggota GPK & 一 \\
\hline $\begin{array}{l}\text { BCA \& Kelompok } \\
\text { Glodok }\end{array}$ & 4-10-1984 & $\begin{array}{l}\text { Chairul } \\
\text { Yunus, dkk. }\end{array}$ & Anggota GPK & $\begin{array}{l}\text { Kasus peledakan } \\
\text { BCA menyeret } \\
\text { lokoh H.M. Sa- } \\
\text { nusi, A.M. Fatwa, } \\
\text { H.R. Dharsono } \\
\text { (anggota Petisi } \\
\text { 50). }\end{array}$ \\
\hline Candi Bórobudur & 20-1-1985 & $\begin{array}{l}\text { Husain Al } \\
\text { Habsy }\end{array}$ & Mubaligh & $\begin{array}{l}\text { Husein menolak } \\
\text { tuduhan dan } \\
\text { menuding } M \text {. } \\
\text { Jawad (tidak } \\
\text { tertangkap) }\end{array}$ \\
\hline $\begin{array}{l}\text { Bis Pemudi } \\
\text { Express, } \\
\text { Banyuwangi }\end{array}$ & $16-3-1985$ & $\begin{array}{l}\text { Abdulkadir } \\
\text { Habsy }\end{array}$ & $\begin{array}{l}\text { Anggota majlis } \\
\text { taklim }\end{array}$ & $\begin{array}{l}\text { dikaitkan de- } \\
\text { ngan peristiwa } \\
\text { Borobudur }\end{array}$ \\
\hline $\begin{array}{l}\text { Plaza Hayam } \\
\text { Wuruk Jkt }\end{array}$ & $15-4-1999$ & lkhwan, dkk & Anggota AMIN & $\begin{array}{l}\text { Kelompok ini } \\
\text { juga dituduh } \\
\text { membom Istiqlal }\end{array}$ \\
\hline Masjid Istiqlal Jkt. & $19-4-1999$ & $\begin{array}{l}\text { Eddy Ranto, } \\
\text { dkk }\end{array}$ & Anggota AMIN & $\begin{array}{l}\text { Ybs, tidak } \\
\text { ditemukan }\end{array}$ \\
\hline
\end{tabular}

(Diolah dari Tempo, Edisi 17-23 Mei 1999) 
dengan mengembangkan kebijakan massa mengambang (floating mass), serta menyeragamkan asas organisasi baik poltik maupun organisasi kemasyarakatan. Efek dari kebijakan tersebut bagi partai politik seperti PPP (fusi dari pelbagai kelompok Islam masa orde lama), dan PDI (fusi kelompok nasionalis dan Kristen) tidak dapat mengorganisasi massa pendukungnya pada tingkat yang lebih bawah (desa, yang justru sebagai basis massa). Masyarakat kebanyakan tidak memiliki orientasi politik apalagi untuk secara jelas memahami arah - politik negara, yang memiliki kemampuan itu hanyalah para elite penguasa ataupun mereka yang duduk sebagai wakil rakyat.

Jika secara jujur mencermati perkembangan sikap politik penguasa terhadap Islam, maka pada banyak lintasan sejarah bangsa ini selalu diwarnai dengan menempatkan Islam dalam posisi yang selalu disalahkan, dan dikalahkan. Pelbagai kondisi yang diciptakan rejim orde baru pada akhirnya menciptakan situasi yang oleh Gurr (dalam saleh, 1996) disebutnya sebagai relative deprivation, dengan umat Islam sebagai kelompok yang terkecewakan. Belakangan, situasi tersebut terakumulasi dalam gerakan-gerakan anarkis (baca: Islam sempalan) yang mengatasnamakan Islam - pemerintah orde baru menyebutkan gerakan-gerakan ini sebagai Gerakan Pengacau Keamanan (GPK)Gerakan pembajakan pesawat oleh kelompok Imron, GPK Warisi, aksi plaza Medan, peristiwa Talangsari, peristiwa Bantaqiah (Aceh), peristiwa Situbondo, Pekalongan, Rangas Dengklok, Tasikmalaya, Klaten, Malang, Tanjung Priok (Idrus, 1997) dan banyak lagi peristiwa serupa di Indonesia yang bernuansa pada kesenjangan rasio antara expected need satisfaction dan actual need satisfaction (James Davis, dalam Saleh, 1996).
Mencermati hal itu ada perbedaan mendasar motivasi masuknya Islam dalam gerakan masa penjajah dengan masa orde baru. Pada periode sejarah bangsa ini hingga menjelang kemerdekaan, Islam dijadikan sebagai simbol perjuangan melawan kekuasaan penjajah. Adapun pada masa pasca kemerdekaan, tampaknya Islam telah masuk dalam wacana politik, dan dijadikan alat pemersatu dalam ikatan emosional (solidaritas mekanik, terminologi yang digunakan Durkheim). Sebut saja gerakan yang dibangkitkan oleh S.M. Karto Soewiriyo ataupun Kahar Muzakkar, merupakan contoh kongkrit upaya membangkitkan emosi umat melalui agama, dan memobilisasi umat untuk bersatu dengan ikatan agama di bawah bentuk negara agama, dan memobilisasi umat untuk bersatu dengan ikatan agama di bawah bentuk negara agama. Begitu juga yang terjadi pada masa-masa orde baru, Islam digunakan sebagai alat efektif untuk memobilisasi massa dengan dalih kesenjangan perlakuan pemerintah terhadap mereka.

Wajah Islam baru "berubah" di mata pemerintah sekitar tahun 1990-an awal, dengan berdirinya Ikatan Cendekiawan Muslim Indonesia (ICMI). Pada masa itulah terjadi "bulan madu" antara Islam dan pemerintah orde baru, dan nuansa ini berlanjut pada pembentukan kabinet hasil pemilu tahun 1992 yang ditengarai "lebih hijau" dari sebelumnya. ${ }^{8}$ Meski demikian, hal ini bukan berarti menghilangkan sama sekali gerakan-gerakan yang bernuansa agama.

BPada masa inilah oleh Kuntowijoyo disebutnya Islam sebagai ide, dengan kelom. pok intelektual sebagai pemuka jalan dan yang berdiri di garda depan. Sebagai ide, Islam tidak lagi diterjemahkan secara ideologis, ataupun mistis, namun secara itmiah (Kuntowijoyo, 1972. Dinamika Sejarah umat Islam di Indonesia. Jakarta: Bulan Bintang. 
Pada lintasan sejarah 1990-an, salah satu kelompok yang tetap eksis menuntut kemerdekaannya adalah gerakan Aceh merdeka (GAM), yang mayoritas pendukungnya beragama Islam. Beberapa gerakan-gerakan yang mengatasnamakan Islam masih pula terdengar, namun semua itu tidak menimbulkan gejolak dan pertumpahan darah yang berarti. ${ }^{9}$

\section{Sempalan Berdasar Ideologi}

Sejarah bangsa ini memang tidak sepi dari pergolakan baik yang bernuansa melawan kekuasaan penjajah, ataupun keinginan-keinginan kelompok melepas dari negara kesatuan Republik Indonesia. Masa sebelum peristiwa kemerdekaan, adalah masa-masa bangsa ini menampilkan seluruh potensi untuk melepas dari kekuasaan penjajah. Pada masa itu, seluruh aktivis pergerakan biasanya bermuara sama, menuntut kemerdekaan -meski pada awalawalnya bersifat kedaerahan, belakangan beralih sifatnya secara nasional-.

Salah satu ideologi yang mendapatkan pengikut banyak selain ideologi kebangsaan dan agama adalah ideologi komunis. Komunisme pada awalnya diperkenalkan oleh seorang Belanda yang datang ke Indonesia tahun 1913, yaitu Hendricus Jo sephus Franciscus Marie Sneevliet, yang dengan Adolf Baars mendirikan Indische sociaal Democratische Vereniging (ISDV) (Noer, 1994). ${ }^{10}$ Meski pada awalnya gerakan ini tidak komunis, namun revolusi mendorong gerakan ini bersalin rupa menjadi perkumpulan komunis. Kelompok ini mendapat simpati dari anggota Sarekat Islam di Semarang yang dipimpin oleh Semaoen.' Pada tanggal 23 Mei 1920 ISDV secara resmi berganti nama menjadi Perserikatan Komunis di Hindia (PKHB) dengan Semaoen sebagai ketuanya.
Pada tanggal 12 Nopember 1926, Semaoen bersama kelompoknya melakukan gerakan yang oleh Harjono (1997) disebut sebagai "revolusi prematur" yang memporak-porandakan posisi barisan pergerakan nasional dalam kancah pergerakan kemerdekaan. Inilah awal gerakan bersenjata yang dilakukan oleh PKI, yang menyulitkan posisi para pemimpin nasional dalam upaya merebut kemerdekaan.

Kegagalan pada pemberontakan itu temyata tidak menjadikannya surut. Dengan dalih membela kepentingan rakyat, kelompok ini ternyata berhasil menyusun kekuatan baru. Tiga (3) tahun setelah peristiwa kemerdekaan (tepatnya 18 September 1948) kembali kelompok ini melakukan aksi kudeta atas pemerintahan yang syah di tengah suasana terjadinya agresi Belanda II. Saat itu. PKI mencoba memproklamirkan berdirinya Negara Republik Soviet Indonesia yang berpusat di Madiun. Gerakan ini berhasil ditumpas oleh pemerintah dengan melakukan operasi "Trisula" dengan mening-

9Mungkin hal ini karena kemampuan menutupi peristiwa tersebut, sehingga tidak terkesan memakan banyak korban. Belakangan terungkap banyaknya peristiwa pembunuhan dan penculikan yang terjadi di Aceh - sebagai daerah yang mengalami DOM-.

${ }^{10}$ Berbeda dengan Noer, Gatra (edisi 5 Oktober 1996) menyebut pendiri ISDV selain Seevliet adalah J.a. Brandsteder dan H.W. Dekker.

"Gorakan Komunis di lubul PSI ini jolits mengguncangkan partai ini, Semaun berpendapat bahwa PKI ini mampu menyatukan rakyat, baik muslim maupun bukan. Melalui beberapa kongres PSI, akhirnya pada kongres keenam di Surabaya pada bulan Oktober 1921 Agus Salim mengajukan resolusi agar kaum komunis (Semaoen Cs) mengundurkan diri dari SI. Tahun 1923 PKHB memisahkan diri dari SI dan mengubah nama menjadi PKI. 
galkan korban di kalangan santri, ulama dan umat Islam lainnya dalam jumlah yang banyak (Gatra, 5 oktober 1996).

Meski kembali gagal, namun satu hal yang harus dicatat adalah kemamuan para elit kelompok ini dalam menanamkan paham ideologinya pada para kader mereka, sehingga kegagalan dalam aksi pemberontakan kedua ini tidak menghilangkan seluruh akar yang pernah ditanam. Kemampuan kelompok komunis dalam menarik simpati massa memang luar biasa. Hal itu terbukti dengan kemampuan mereka tampil kembali dalam pemilu tahun 1955.

Dalam catatan Ma'arif (1993) PKI mampu memposisikan diri sebagai partai yang termasuk dalam kelompok empat besar selain PNI, Masyumi, NU, dengan perolehan jumlah kursi di parlemen sebesar 39. Lazimnya sebagai salah satu kelompok pemenang pemilu, PKI berhak masuk dalam kabinet pemerintahan yang akan dibentuk, namun Masyumi dan NU menolak kehadiran mereka dalam kabinet tersebut. Hal inilah yang menjadi salah satu ganjalan yang dirasakan oleh Presiden Soekarno yang menginginkan terjadinya balanching dalam kabinet. Dimulailah perseteruan antara PKI di satu sisi dan Islam di sisi lain.

Dalam upayanya menarik Presiden Soekarno, PKI giat mempropagandakan ide-ide yang diajukan Soekarno. Bahkan dalam satu kesempatan Nyoto (tokoh polit biro CCPKI) memberi masukan pada konsep pidato yang akan dilakukan Soekarno pada tanggal 17 Agustus 1959. yang oleh Soekarno diberi judul "penemuan kembali revolusi kita". Saat itulah Soekarno mengucapkan Manifesto Politik (Manipol), bahwa demokrasi liberal telah gagal, dan harus digantikan dengan demokrasi terpimpin. Dalam demokrasi terpimpin "organisasi-organisasi masyarakat harus diretool. Partai-partai politik, badan-badan sosial di-retool, badan-badan ekonomi
diretool"'(Gatra, 1996).

Saat Soekarno mengucapkan pidato yang berjudul "Djalannya revolusi kita" tanggal 17 Agustus 1960, Bung Karno mengemukakan gagasan Nasakom (Nasionalismeagama-komunisme). Saat ini pula, PKI "meminjam tangan" Soekarno untuk menghancurkan Masyumi lawan politik mereka yang tangguh dengan munculnya Keputusan Presiden No. 200/1960 tentang pembubaran partai politik. Salah satu alasan yang diajukan PKI untuk mendukung lobi mereka adalah tokoh partai-partai tersebut terlibat dalam.aksi pemberontakan PRRl/ Permesta.

Pada masa orde lama, komunis dapat dikatakan mencapai titik jayanya. Se- tidaknya gagasan NASAKOM yang dipopulerkan Soekarno pada penghujung akhir 1960 merupakan salah satu wujud dari keberhasilan łobi yang dilakukan oleh elit biro partai komunis ini. Selain itu, jika dicermati pada masa-masa tersebut, komunis telah memiliki basis yang cukup kuat. $\mathrm{Hal}$ tersebut dapat diamati dari dukungan beberapa jenderal di jajaran Angkatan Bersenjata, atau pada meluasnya dukungan rakyat pada beberapa kota di Jawa. Pada peringatan ulang tahun PKI tanggal 23 Mei 1965 di senayan, DN Aidit (Ketua CCPKI) mengklaim bahwa anggota $\mathrm{PKI}$ di seluruh Indonesia berjumlah 3 juta orang anggota aktif, dan 20 juta simpatisan (Gatra, 1996).

Merasa memiliki basis yang kuat, serta memiliki persiapan yang mapan, kembali PKI melakukan aksi pemberontakan yang mereka lakukaı pada talıun 1065 - di kemudian hari gerakan ini dikenal dengan nama Gerakan 30 September (G.30.S) sesuai waktu kejadian-. Lagi-lagi bangsa Indonesia dikelabui dengan sikap manis $P K I$ ini. Buah dari gerakan ini sangat luar biasa, betapa banyak sekali nyawa yang harus dikorbankan demi gerakan itu. 


\section{Etis, Potensi Lain Menyempal}

Di luar dari dua kategori kelompok yang pernah terlibat sebagai kelompokdissidend kelompok lain yang memilikipeluang untuk melakukan hal serupa adalah kelompok etnis dan kedaerahan. Pada masa penjajahan dapat disaksikan betapa ikatan kedaerahan dan suku mampu menupakan salah satu cara efektif untuk menggalang kekuatan melawan kekuasaan. Dari sejarah ini dapat disimpulkan betapa etnis/suku/ras mampu menjadi pengikat untuk aksi menyempal baik dengan perlawanan bersenjata - seperti kebanyakan yang dilakukan para pejuang daerah-. ataupun gerakan tanpa senjata seperti yang dilakukan Surosentiko Samin, dengan gerakan Saminnya.

Pasca kolonial, memang tidak kita saksikan gerakan-gerakan yang mengatasnamakan etnis yang menonjol. Begitu juga pada masa orde lama terlebih pada masa orde baru. Hal tersebut mungkin begitu kuatnya negara meredam gerakan-gerakan separatis semacam itu, atau mungkin klasifikasi itu tidak kita temukan karena kerapnya negara mengelompokkan gerakan semacam itu pada satu istilah GPK (Gerakan Pengacau Keamanan).

Gerakan atas nama etnis baru menyenk pasca.lengsernya Soeharto sebagai presiden. Tuntutan akan kemerdekaan mulamula muncul dari kelompok CNRT (Dewan Perlawanan Nasional Bangsa Timor) dan GAM (Gerakan Aceh Merdeka). Diawali dari peluang yang diberikan BJ. Habibie -selaku presiden- yang menawarkan opsi otonomi penuh atau merdeka, maka menjelang berakhirnya milenium kedua ini Indonesia harus melepas salah satu propinsinya, Timor-Timur untuk merdeka.

Peluang ini menjadi pemicu keinginan serupa pada beberapa etnis tertentu, sebut saja Irian Jaya (sejak 1 Januari 2000, secara resmi disebut Papua), Riau, Kaliman- $\tan$ Timur, atau Aceh. Meski para penuntut hak kemerdekaan tidak dapat sepenuhnya dikatakan mewakili keinginan seluruh masyarakat yang bersangkutan, namun teno mena ini harus disikapi secara lebih bijak.

Tampaknya dalam menghadapi gerakan-gerakan yang berlatar belakang etnis ini, pemerintah harus melakukan koreksi ke dalam. Setidaknya salah satu yang melatarbelakangi munculnya tuntutan tersebut adalah terjadinya kesenjangan antara pusat dan daerah. Betapa tidak sebandingnya antara kewajiban "setor" yang dilakukan oleh daerah mereka, menjadi salah satu pemicu munculnya tuntutan ini. Harus diakui bahwa kebanyakan masyarakat daerah-daerah -yang menuntut kemerdekaan- hidup dalam kondisi kemiskinan. Ironisnya daerah mereka merupakan penyumbang devisa terbesar negara ini. Kondisi ini tentu saja menimbulkan kecemburuan yang sangat besar, terlebih dari hasil daerah mereka hanya diakui kalangan tertentu yang berada di Jakarta.

Selain itu pada beberapa daerah tertentu, pemerintah-pemerintah terdahulu telah melakukan banyak aktivitas yang membawa banyak korban berjatuhan. Tentu saja hal tersebut menambah luka hati yang mereka rasakan, yang terakumulasi menjadi "dendam" yang harus tersampaikan.

\section{Peluang Bangkit}

Mencermati papan di muka, lantas muncul satu pertanyaan mungkinkah kelompok-kelompok ini bangkit kembali dan melakukan gerakan sempalan? Untuk menjawab pertanyaan ini memang membutuhkan satu data empirik. Meski demikian, ada beberapa prasyarat yang harus dipenuhi para penguasa agar tidak terjadi bangkitnya kelompok-kelompok sempalan dari manapun asalnya. 
Pertama, banyak aktivitas gerakan sempalan dipicu dari kesenjangan yang terjadi antara harapan yang mereka miliki de ngan runtuhnya harapan itu. Sebagai misal adanya diskriminasi partisipasi politik, ekonomi. Kondisi-kondisi ini harus dihilangkan oleh pemerintah dengan memberi peluang tanpa pemihakan. Mestinya situasi orde banu yang melakukan diskriminasi pada ba nyak aspek tidak lagi terjadi pada pemerintahan pasca orde baru.

Kedua, mengarah kontlik yang terjadi konteks positif. Pada dasamya konflik akan terjadi pada segala situasi kehidupan, dan konflik politik terjadi karena adanya kemajemukan horisontal dan kemajemukan vertikal (Nasikun, 1974). Konflik sebagai akibat kemajemukan horisontal muncul karena pada kelompok masyarakat terdapat pelbagai kepentingan yang berbeda, sedangkan kemajemukan vertikal terjadi karena penguasaan sumber-sumber oleh sekelompok kecil masyarakat.

Merujuk pada Nasikun, maka penyelesaian atas konflik itu harus berupa konsiliasi (ada kesepakatan pihak yang konflik); mediasi (merujuk pihak ketiga menyelesaikan konflik) dan arbitrase (pihak yang terlibat menghadirkan pihak ketiga untuk menengahinya). Dalam posisi ini pihak pemerintah harus seoptimal mungkin mengambil peran dalam penyelesaian konflik, tidak lalu memberikan pihak yang terlibat untuk menyelesaiannya sendiri - fenomena kasus Ambon-.

Ketiga, satu ideologi secara naluriah akan terwariskan dari satu generasi ke generasi lain baik melalui enkulturasi ataupun akulturasi budaya. Artinya, dalam upaya mencegah satu ideologi bangkit pemicu kelompok sempalan bukan dengan cara menekan ideologi tersebut, atau bahkan mengharamkan diskursus tentang ideologi itu. Terlebih saat ini, canggihnya media elektronik tidak dapat dihalangi oleh pemerintah dengan membendung arus informasi yang masuk. Untuk itu diskursus satu ideologi apapun ideologi itu harus diberi peluang secara terbuka. Kasus PRD menjadi catatan betapa perlu adanya dialog dan pelurusan tentang konsep yang diperdebatkan.

Keempat, ada keberanian dari pemerintah untuk menegakkan' hukum sebagaimana mestinya. Salah satu persoalan di banyak negara ketiga adalah, lemahnya posisi hukum dalam menghadapi orangorang yang memiliki akses kekuasaan, sementara hukum begitu kuat jika menyangkut orang-orang yang tidak berdaya. Peristiwa "Udin" wartawan Bernas memperlihatkan mudahnya hukum dipermainkan oleh kalangan tertentu. Mestinya situsi ini harus segera dibenahi, dengan menempatkan semua orang berposisi sama di mata hukum:

Pada masa orde baru kita saksikan betapa banyak tejadi pelanggaran-pelanggaran HAM yang tidak memperoleh penyelesaian secara proporsional. Kasus yang terjadi pada peristiwa Tanjung Priok 1984, 27 Juli 1996 di Jakarta, saat terjadi penyerangan kantor DPD PDI, peristiwa Banyu. wangi, Ambon. Timor-Timur, dan Aceh menjadi cermin buram pelaksanaan HAM di Indonesia. Situasi-situasi tersebut dapat menjadi sumber konflik yang mengarah pada disintegrasi.

Kelima, menghilangkan kultus individu. Kondisi ini harus segera dihilangkan agar tidak terjadi kondisi seperti pada masa orde lama dan ordo baru. Jika socara cormal diamati, tampaknya situasi ini akan menjerat pucuk pemerintahan kita saat ini. Harus diakui baik Gus Dur (Presiden KH. Abdurrahman Wahid) dan Mbak Mega (lbu wakil Presiden Megawati Soekarno Putri) memiliki basis massa yang banyak, dan tidak jarang di antara pendukung beliau berdua demikian patuhnya (samina wa 
atho'na). Meskipun demikian, seharusnyalah mereka tidak kebal kritik sebagaimana didengungkan sebagai awal komitmen mereka dalam rangkaian reformasi. Untuk itu kesadaran para pendukungnya bahwa mereka juga punya peluang dikritik harus pula ditanamkan, dan tidak menganggap bahwa mereka maksum dari kesalahan. ${ }^{12}$

Di luar itu, potensi terjadinya kelompok sempalan dapat berakar pada potensi ideologi dan etnis. Seperti telah dibuktikan sejarah betapa komunisme tidak dapat hilang begitu saja dengan hancurnya gerakan yang mengatasnamakannya. Pada setiap perjalanan sejarah selalu ditemukan unsur-unsur ke arah sana. Meski demikian, pemerintah hendaknya bersikap lebih arif dengan tidak tergesa-gesa mengelompokkan satu gerakan pada paham ini. Sebagai misal, lahirnya PRD (Partai Rakyat Demokratik) pada awalnya ditengarai sebagai kelompok komunis. Tentu saja cap ini bagi pemerintah saat itu membawa dampak ditahannya para pemimpin PRD. Namun, tatkala kekuasaan Soeharto berakhir, PRD justru menjadi salah satu kontestan pemilu 1999. Pertanyaan yang muncul, telah bergeserkah konsep pemerintah dalam memandang "komunis" sebagai satu ideologi? atau hal ini pertanda awal bangkitnya kembali kelompok-kelompok sempalan?

Terlepas dari itu, yang harus disadari oleh komponen bangsa meski banyak kalangan yang menyatakan komunis telah hancur bersama PKI tahun 1965 lalu, namun ideologi tersebut tampaknya tidak pemah mati. Memang yang harus dicari adalah "die hard" aktor intelektual aktivitas gerakan tersebut. Mereka dapat beralih rupa dengan dalih agama, etnis, atau apapun untuk mensosialisasi ide-ide mereka. Pada banyak kasus, kita selalu menyatakan ada "provo kator" namun tanpa sempat menyaksikan siapa dia? Semoga masa yang akan datang, identitas mereka akan jelas terlihat, semoga.•

\section{Kepustakaan}

Ali, Fachry. 1997. Kewibawaan Pendidikan Islam sebagai wacana keberadaan dalam Muslih Usa dan Aden Wijdan S.Z. (Penyunting) Pendidikan Islam dalam Peradaban Industrial. Hal 220228 Jakarta: Fakultas Tabiyah UII Yogyakarta.

Benda Harry. J, 1987. Kontiunitas dan Perubahan dalam islam di Indonesia. dalam Taufik Abdulah (Editor). Sejarah dan Masyarakat: Lintasan Histori Islam di Indonesia. Hal 2653. Jakarta: Yayasan Obor.

DeGraff, H.J. 1985. Awal Kebangkitan Mataram, Masa Pemerintahan Senopati. Jakarta: PT. Graffiti Pers.

Gatra. Edisi 5 Oktober 1999. Jakarta: Era Media Informasi.

Harjono, Anwar. 1997. Perjalanan Politik Bangsa: Menoleh ke belakang menatap Masa Depan. Jakarta: Gema Insani Press.

Idrus, Muhammad., 1997. Ukhuwah Islamiyah sebuah Peradaban Baru? dalam Jurnal Mukadimah No.4 Yh. III/1997. Hal 120-127. Yogyakarta: Kopertis Wilayah III dan PTAIS DIY.

Kuntowijoyo, 1972. Dinamika Sejarah Umat Islam di Indonesia. Jakarta: Bulan Bintang.

${ }^{12}$ Fenomena Bagilo (group lawak) yang terpleset lidah menjadi pelajaran betapa tuntutan pendukung Gus Dur melebihi apa yang disikapi oleh Gius Dur sendiri. Jika hal ini terus berlangsung, maka tidak ada lagi yang berani jujur menyatakan apa yang seharusnya dikatakan demi keselamatan dan kesenangan atasan. 
Topik: Kelompok Sempalan: Sisi Lain Dinamika Politik Kita, Muhammad Idrus

Maarif., A. Safii., 1993. Peta Bumi intelektualisme Islam di Indonesia. Bandung: Mizan.

1995. Membumikan Islam, Yogyakata: Pustaka Pelajar.

Nasikun, J. 1974. Sebuah Pendekatan untuk Mempelajari Sistem Sosial Indonesia. Yogyakarta: Fisipol UGM.

Noer,. Deliar., 1994. Gerakan Modem Islam di Indonesia 1990-1940. Jakarta: LP3ES.
Rahardjo, D. Dawam., 1988. Agama, Masyarakat dan Negara dalam Mukti Ali Agama dalam Pergumulan Masyarakat Kontemporer. Hal 129-48. Yogyakarta: Tiara Wacana.

Saleh, Hasanudin M., 1996. HMI dan rekayasa asas tunggal Pancasila. Jakarta: Kelompok Studi Lingkaran.

Suryanegara, Ahmad Mansur. 1995. Menemukan Sejarah: Wacana Pergerakan Islam di Indonesia. Bandung: Mizan.

Tempo. Edisi 17-23 1999. Jakarta: PT. Arsa Raya Perdana. 